\title{
Long-term changes in the tree and shrub layers of a British nature reserve and their relevance for woodland conservation management.
}

\author{
K. J. Kirby ${ }^{\mathrm{a}}$, E. A. Goldberg ${ }^{\mathrm{b}}$, R. Isted ${ }^{\mathrm{c}}$, S. C. Perry ${ }^{\mathrm{b}}$ and R. C. Thomas ${ }^{\mathrm{b}}$ \\ a Department of Plant Sciences, South Parks Road, Oxford OX1 3RB, UK. keith.kirby@bnc.oxon.org \\ ${ }^{\mathrm{b}}$ Natural England, Suite D, Unex House, Bourges Boulevard, Peterborough PE1 1NG, UK \\ 'Forestry Commission England, 620 Bristol Business Park, Bristol BS16 1EJ, UK \\ Corresponding author: Keith Kirby, keith.kirby@bnc.oxon.org \\ Email addresses for other authors: emma.goldberg@naturalengland.org.uk ; \\ Suzanne.perry@naturalengland.org.uk ; Rachel.thomas@naturalengland.org.uk ; \\ Rebecca.isted@forestry.gsi.gov.uk
}

\begin{abstract}
Changes in the woodland extent over the last 200 years were assessed from old maps for a 100 ha woodland nature reserve in southern Britain. More detailed changes in the composition and structure of the tree and shrub layers were measured using data from 95 permanent vegetation plots $(10 \times 10 \mathrm{~m})$ distributed across the reserve at the intersections of a $100 \mathrm{~m}$ grid. These were recorded in 1973, 1992 and 2009. The woodland area has more than doubled since the $18^{\text {th }}$ century, but whereas the pre- 1800 woodland was mainly Fagus sylvatica the more recent woodland was initially predominantly conifer plantation. These plantations have since developed into mainly broadleaved high forest of Fraxinus excelsior and Acer pseudoplatanus. Changes on the site are the combination of active interventions through management and natural processes (differential species growth, death from disease, windthrow, herbivore damage). Further changes are likely in future in particular from ash dieback (Hymenoscyphus fraxineus) and climate change impacts. Many of the changes seen on this reserve are mirrored in woods elsewhere in Britain and Europe. Over periods of a few decades and at the wholereserve scale the woods can be considered to be relatively stable; at the plot level, or over time-scales of centuries they are very dynamic. Whether woods are judged to be resilient must include definition of the temporal and spatial scales.
\end{abstract}

Keywords: long-term monitoring; beech forest; stand dynamics; nature reserve; ash dieback; sycamore

\section{Introduction}

In Britain, as in much of Europe and eastern north America, woodland exists as part of cultural landscapes with a long history of human intervention (Rackham 1986, 2003; Foster et al. 1998; Kirby \& Watkins 2015). The structure and composition of woods, stands and even the shapes of individual trees reflect the legacies of past land-use change, woodland management or neglect. These in turn reflect the objectives of the owners and users of the woods (e.g. von Oheimb \& Brunet 2007; Lindbladh \& Foster 2010; Kirby et al. 2014; Rochel 2015). Overlain on these deterministic forces are the effects of natural processes such as tree growth, storms, droughts, pests and diseases, herbivore damage, fire etc. (Koop \& Hilgen 1987; Kirby \& Buckley 1994; Peterken \& Mountford 1996, 1998; Pontailler et al. 1997; Mountford 1997, 2006; Mountford et al. 1998; Mountford \& Peterken 1998, 
2003; Emborg \& Heilmann-Clausen 2007; Brunet et al. 2014; Latałowa et al. 2015; Müllerová et al., 2015).

Permanent plot studies can be invaluable in allowing direct observation of long-term changes, their causes and consequences e.g. Bakker et al. (1996), Peterken and Jones (1987, 1989), BarkerPlotkin \& Foster (2006), Perrin et al. (2006). However, researchers generally only stay with a site for a few decades, because of changes to their jobs, or their interests, and ultimately their lifespans. Coupling analysis of historical maps and accounts with long-term monitoring data can help to identify and interpret older events that have legacies in today's woods; comparison with nearby sites or national data may allow the separation of site-specific from more general patterns (Magnuson 1990).

We illustrate this approach through a study of the changes in the tree and shrub layer of a woodland nature reserve in southern Britain. Our data come from permanent vegetation plots established in 1973 by Dawkins and Field (1978), with subsequent recordings in 1992 and 2008-10, together with insights from maps dating back to the middle of the $18^{\text {th }}$ century.

Studies of long-term woodland change in various protected sites in Britain have mainly been based on transects in ancient semi-natural stands under minimum intervention treatments (Peterken \& Backmeroff 1988). The systematic plot distribution set up by Dawkins and Field (1978) at the Warburg Reserve described here, and at Wytham Woods about thirty kilometres to the north-west (Kirby et al. 2014) also cover areas of recent plantations and actively managed stands. This allows for the description of influences on the composition and structure of woodland that may be more typical of the bulk of British broadleaved woodland. We show how the composition and structure of the reserve has changed over the last 200 years as a consequence, and discuss some implications for the future treatment of the reserve.

\section{Site}

The Warburg Reserve, c. 100 ha, lies at $51^{\circ} 35^{\prime} 7^{\prime \prime}$ north/05’ 3” west, British national grid reference SU717879 (BBOWT 2016). It is owned and managed by the Berkshire, Buckinghamshire and Oxfordshire Wildlife Trust (Paul 1985; Phillips 1991) and forms part of a larger block of woodland in the Chiltern Hills of southern Britain (Tilney-Bassett 1988; Natural England 2013).

The reserve covers the sides of a dry valley (90-165 m above sea level) consisting of two north-south running sections connected by a middle east-west section. Mean temperature ranges from $2.7^{\circ} \mathrm{C}$ in January to $15.8^{\circ} \mathrm{C}$ in July, with an annual rainfall of $711 \mathrm{~mm}$. Most of reserve lies on Cretaceous Upper Chalk, with just a narrow belt along the valley bottom on the Middle Chalk. Much of the chalk is covered by various superficial deposits, such that while many of the soils are calcareous, there are locally areas where the surface layers have been heavily leached.

\section{Conservation significance}

The reserve was acquired by the Wildlife Trust in 1967 when its value as a site for rare plants, particularly orchids, was being threatened by unsympathetic management for timber production (Paul 1985). The reserve was designated as a Site of Special Scientific Interest (the statutory mechanism for protecting important nature conservation sites in Britain) in 1972 because of its complex mosaic of ancient beech and ash woodland, scrub and a small extent of species-rich chalk grassland. Over 500 species of vascular plants have been recorded from the reserve and it also hosts diverse invertebrate and fungal populations. 
The woodland is a mixture of British National Vegetation Classification types W12 Fagus sylvatica-Mercurialis perennis woodland (mainly in the ancient woodland) and W8 Fraxinus excelsior-Acer campestre-Mercurialis perennis woodland (mainly in the stands of more recent origin) (Rodwell 1991). The grassland areas are a mixture of Festuca ovina-Avenula pratensis CG2 and the Avenula pubescens CG6 communities (Rodwell1992). Both the beech woodland and the calcareous grassland types are priority habitats under the UK Biodiversity Action Plan (Anon 1994) and are listed under Annex I of the European Habitats Directive (European Commission 1992).

\section{Historical context}

Britain's woodland cover had shrunk to about $5 \%$ by AD 1900, as a consequence of thousands of years of clearance, primarily to create farmland. Such woods as survived tended to relatively small and were managed intensively as part of the local rural economy (Rackham 2003). Thus in the $18^{\text {th }}$ and early $19^{\text {th }}$ centuries the main markets for produce from woods such as that which would become Warburg Nature Reserve were for small roundwood produced by coppice or pollard systems (Edlin 1949; Rackham 2003). This material would almost certainly have been used in the brickworks in the nearby village.

In the second half of the $19^{\text {th }}$ century an agricultural recession in Britain, caused by factors such as increased imports of grain and meat, led to declines in the value of farmland. Where, as in this study area, the land was put into woodland, shifts in the timber market favoured the creation of productive plantations of introduced conifers (Aldhous 1997). However the conifers were noted as growing badly almost from the start, probably due to lime chlorosis on these calcareous shallow soils (Tilney-Bassett 1988) and broadleaves invaded many of the gaps that developed in the crops as trees died or following felling during the Second World War (1939-1945) (Phillips 1991).

The objectives of management for the study site changed again in 1967 when the reserve was acquired by the Wildlife Trust (Paul 1985). Priority was given to maintaining the ancient woodland and the range of other semi-natural woodland and grassland habitats present (Phillips 1991), with some small areas managed as coppice or scrub. There is currently a presumption against any further tree planting.

\section{Methods}

Woodland origin

The origin of different parts of the woodland within the reserve was inferred from examination of the topographic maps (1:10560) produced at various dates through the $19^{\text {th }}$ and $20^{\text {th }}$ centuries by the UK Ordnance Survey maps (Old-Maps.co.uk undated) supplemented by information from earlier surveys and maps (c.1750 and1824) examined by Webb (1987) and summarised in Phillips (1991). Areas were allocated to the different origin periods as follows: ancient woodland (present pre-1800); early $19^{\text {th }}$ century (present by 1824); late $19^{\text {th }}$ century (present by 1900 ); plus some small areas that appear never to have been wooded.

\section{Field work}

In 1973 a $100 \mathrm{~m}$ grid was marked out on the reserve and a $10 \times 10 \mathrm{~m}$ vegetation plot recorded at the intersection points, with metal markers put in at the plot corners to aid relocation (Dawkins \& Field 1978). In 1992 (Kirby \& Thomas 2000) and between 2008 and 2010 the plots were re-recorded using the same methods as used in 1973. The 2008-2010 recording is hereafter referred to as the 2009 
record. There are 102 plots, but 6 plots, for unknown reasons, were not recorded in the 1973 survey (although they have been since) and 1 plot was not recorded in 2009 because it was in the middle of exceedingly dense scrub. Consequently only the 95 plots for which there are three sets of data are used in this analysis.

Within each plot the following estimates or measurements were made:

- The occurrence of all woody species in the plot was noted;

- The DBH - diameter at breast height (1.3 m) - was measured for the four largest trees in the plot, regardless of their species;

- 'Overstorey' cover (at $>2.5 \mathrm{~m}$ ), split by species and 'understorey' cover (all species) (0.5-2.5 $\mathrm{m}$ ) were estimated across the north-west/south-east diagonal of the plot using a percentage scale;

- Regeneration (the presence of seedlings, saplings, or vegetative regrowth such as rootsuckers, up to $1 \mathrm{~m}$ tall) was recorded in thirteen $0.1 \mathrm{~m}^{2}$ circlets positioned evenly along the two diagonals of the plot.

- The mean basal area of the trees at the plot location was estimated by relascope sweeps from the plot corners. Relascope sweeps are a form of angle gauge sampling. All visible tree stems (not just those in the plot) are viewed through the relascope and their apparent diameter compared with a scale band; trees that appear equal to or wider than the scale band are counted in a $360^{\circ}$ sweep. A large tree will thus count at a greater distance than a small tree. The number of trees that count on a sweep is multiplied by a conversion factor, depending on the particular scale band used, to give the mean basal area per hectare at that point (Bitterlich 1984; Wikipedia 2008).

Changes in the composition of the overstorey and understorey across the whole reserve since 1974 were assessed in terms of species occurrence, cover and, for the tree species, basal area. The DBH distribution for largest trees in the plots indicates the broad age structure of the populations of different species. The distributions of the main tree species in relation to woodland origin were compared. The various introduced coniferous species (mainly Pinus spp., Picea abies, Pseudotsuga menziesii) have been grouped together, while the native yew (Taxus baccata) has been included with 'other broadleaves'. We concentrate on comparisons between the 1973 and 2009 results, because the changes in the two recording periods (1973-1992, 1992-2009) tended to be consistent.

Nomenclature follows Stace (1991).

The impact of past and future tree diseases

Between 1973 and 2009 the reserve was affected by Dutch elm disease caused by the fungus Ophiostoma novo-ulmi (Gibbs 1978). The plot records were used to assess the scale of impact of this disease on the reserve.

A future concern for the reserve managers is ash dieback, caused by Hymenoscyphus fraxineus (Patausso et al. 2013) which is expected to reach the reserve in the next few years. Largescale death of ash (Fraxinus excelsior) could have implications for a wide range of associated species (Mitchell et al. 2014). Plots were grouped according to whether there was more than $20 \%$ ash recorded in the overstorey to indicate where gaps were most likely to develop. Where ash was more than $20 \%$, the plots were grouped according to whether there was more or less than $25 \%$ of other 
species in the overstorey as a measure of the potential for other species to expand into the gaps created.

\section{Results}

\section{Woodland origin}

Based on the old maps consulted, about $40 \%$ of the area has been wooded since at least AD 1800 (Table 1) and is probably ancient (Spencer \& Kirby, 1992; Goldberg et al. 2007). The two ancient blocks have become linked through several phases of planting on former fields over the last 200 years (Figure 1 ).

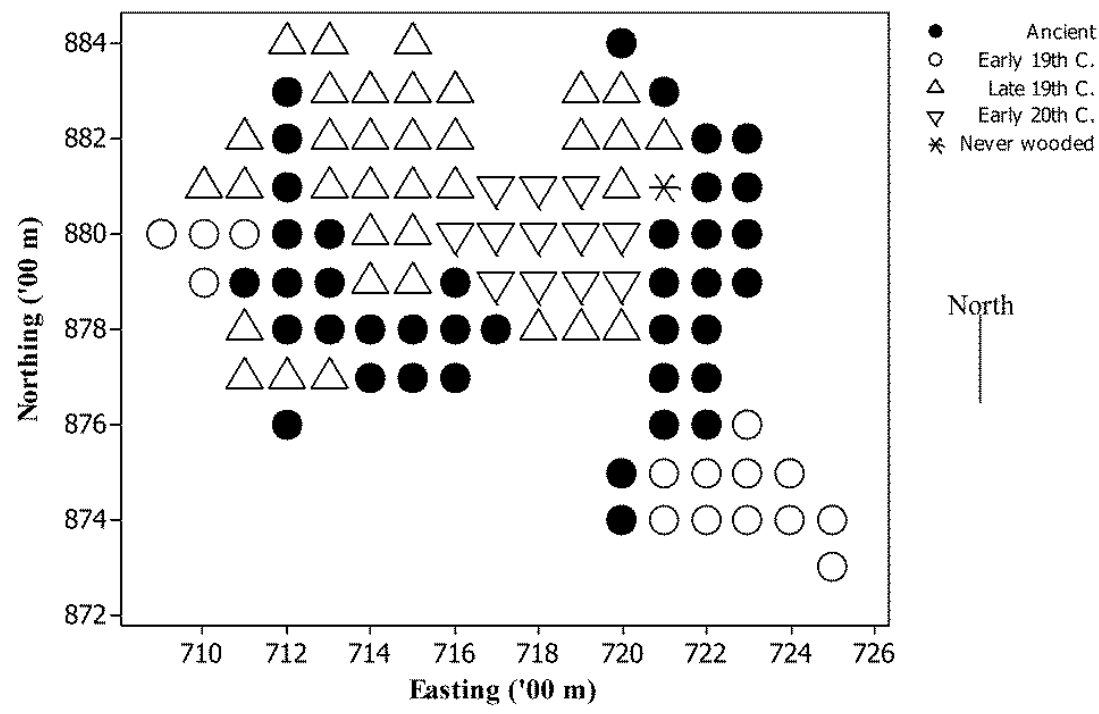

Figure 1. Distribution of plots at the Warburg Reserve by woodland origin. The axes are UK National Grid values, each unit being $100 \mathrm{~m}$.

Species-rich grassland occurred mainly as an open strip created as a rifle range and along some of the wide rides. In the 45 years since the reserve was acquired by the Wildlife Trust the open areas have expanded (by c.10 ha) through clearances of the more recent woodland to create/restore more species-rich calcareous grassland.

Table 1. Historical origin of different areas of woodland

\begin{tabular}{llr}
\hline Woodland origin & $\begin{array}{l}\text { Earliest map date showing area as } \\
\text { woodland }\end{array}$ & No of plots \\
\hline Ancient woodland (pre-1800) & Pre-1800 & 36 \\
Early 19 $9^{\text {th }}$ century woodland & 1824 & 14 \\
Late 19th century woodland & 1898 & 33 \\
Early 20 $0^{\text {th }}$ century woodland & 1919 & 11 \\
Never wooded & & 1 \\
\hline
\end{tabular}

Changes in woodland structure in the last 45 years

Mean overstorey cover per plot showed little change over 45 years $(75 \pm 3.4 \%$ in 1973,78 \pm 2.5\% in 2009), but this masks substantial changes at the plot level (Figure 2). Between 1973 and 2009 
a quarter of plots showed a cover change of at least 30\%. Large increases in overstorey cover were seen in plots in the south-east of the reserve, where the overstorey had been relatively open in 1973 because of felling and replanting in 1963. The reductions in overstorey cover were more scattered across the reserve and include plots under plantation in 1973 that were subsequently cleared of trees to restore species-rich grassland; plots cut as part of small scale coppice management; and plots that were badly affected by windblow, particularly a major storm in January 1990. Trees partly or completely blown over, but still living were not uncommon through the reserve.

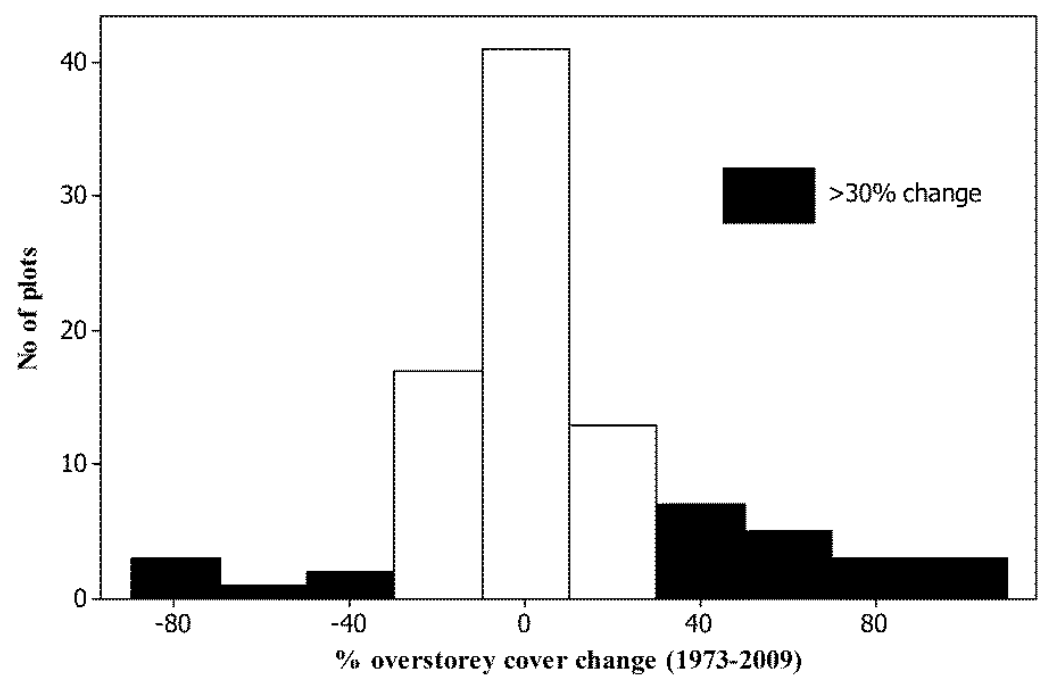

Figure 2. Change in the overstorey percentage cover (1973-2009) of individual plots at the Warburg Reserve.

The mean understorey layer cover per plot declined (32\% \pm 2.9 in 1973, 21\% \pm 2.2 in 2009). The change in individual plots tended to be the converse of the overstorey change - plots that had been dense thickets opened out below as the trees grew taller; partially cleared plots developed into thick understorey layers (Figure 3). However this only explained $16 \%$ of the variation. Deer browsing was also a contributory factor as indicated by the pronounced browse-line in places at about $2 \mathrm{~m}$ high from the impact of deer, particularly fallow deer (Dama dama L.).

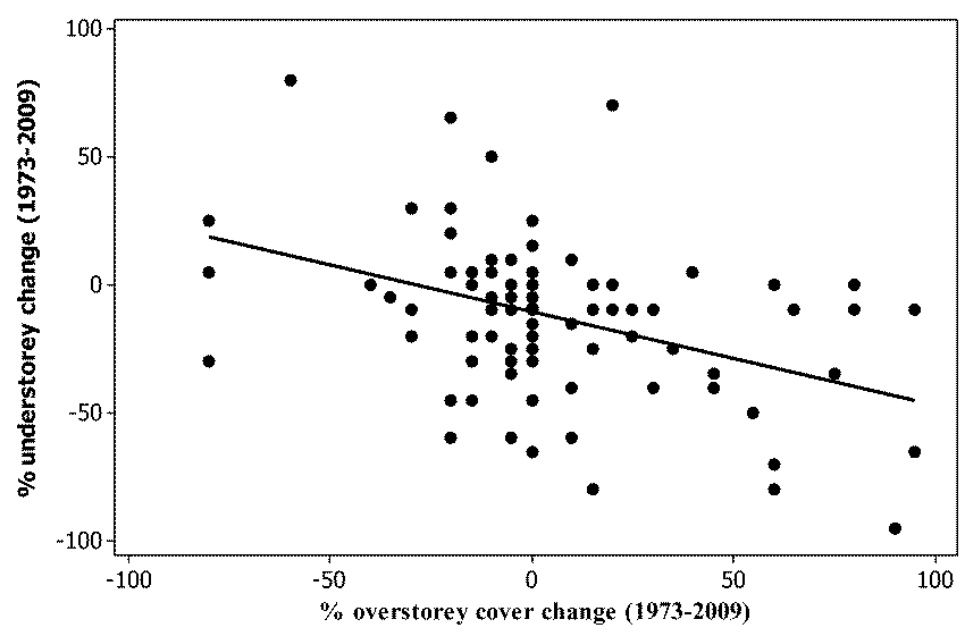

Figure 3. Change in the understorey layer compared to change in the overstorey for the same plot (1973 -2009) at the Warburg Reserve. Regression equation: Understorey cover change $=(-10.2)$ $0.364 *$ overstorey change $\mathrm{p}=0.001, \mathrm{R}^{2}=16 \%$ 


\section{Changes in overstorey and understorey composition}

In 1973 beech (Fagus sylvatica) (19.8 \%) and ash (Fraxinus excelsior) (15.4\%) made the largest contributions to the tree layer, measured by overstorey cover, followed by sycamore (Acer pseudoplatanus) (Table 2). Ash was more common across the site based on the number of plots in which it occurred. It was the only tree regularly recorded as regeneration in the circlets, but most of these were first-year seedlings. In 2009 in $67 \%$ of the plots where ash regeneration occurred the tallest ash seedling was less than $10 \mathrm{~cm}$ high; in only $8 \%$ of plots was the tallest ash regeneration more than $20 \mathrm{~cm}$; and only one plot had an ash sapling more than $30 \mathrm{~cm}$. Ash was also the species showing the greatest increase in cover over the recording period; by 2009 it had overtaken beech and made up 25.7 $\%$ of the overstorey.

Field maple (Acer campestre) occurred in 35-45\% of plots but mainly in the understorey and so contributed little to the overstorey layer. Oak (Quercus robur) and birch (Betula spp.) occurred in fewer plots in 2009 than in 1973, but maintained their overstorey cover contribution. Introduced conifers, i.e. excluding yew (Taxus baccata) were present in about a quarter of the plots and contributed about $10 \%$ of the cover overall in 1973, but their contribution declined over the recording period. The non-native broadleaved tree - Quercus cerris - was recorded from twenty-two plots in 1973 but only one in 2009.

Hazel (Corylus avellana) and hawthorn (Crataegus spp.) were each present in more than half the plots at all three recording times, but only hazel made much of a contribution to the overstorey layer (Table 2). Dogwood (Cornus sanguineus) was common in the 1973 records but declined greatly by 2009 and there were fewer records for the other shrub species as well, probably because they had been overtopped in plots where the tree layer had increased. Shrubs were more common than tree species amongst the regeneration recorded in the circlets. Much of this was vegetative regrowth from stumps or roots.

\section{Changes in basal area and tree size distributions}

The basal area of the trees more than doubled between 1973 and 2009 (Table 3) with ash contributing almost half the total gain and substantially increasing its proportion of the total. The overstorey cover of conifers was reduced through felling and tree death but those that remain had grown bigger: hence the conifer basal area was maintained in absolute terms, although reduced as a proportion of the total. 
Table 2. Occurrence, overstorey cover and regeneration of main woody species in 1973, 1992 and 2009 in the Warburg Reserve.

\begin{tabular}{|c|c|c|c|c|c|c|c|c|c|}
\hline \multirow[b]{2}{*}{ Recording time } & \multicolumn{3}{|c|}{$\begin{array}{l}\text { Occurrence (no of } \\
\text { plots in which } \\
\text { species recorded } \\
\text { out of 95) }\end{array}$} & \multicolumn{3}{|c|}{$\begin{array}{l}\text { Mean \% cover in overstorey } \\
\text { across diagonal of plot } \\
\text { ( } \pm \text { standard error) }\end{array}$} & \multicolumn{3}{|c|}{$\begin{array}{l}\text { No of plots with } \\
\text { regeneration in at } \\
\text { least one circlet }\end{array}$} \\
\hline & 1973 & 1992 & 2009 & 1973 & 1992 & 2009 & 1973 & 1992 & 2009 \\
\hline \multicolumn{10}{|l|}{ Main broadleaved trees } \\
\hline Fagus sylvatica & 32 & 26 & 31 & $19.8 \pm 4$ & $20.5 \pm 4$ & $23.2 \pm 4$ & 5 & 5 & 1 \\
\hline Fraxinus excelsior & 60 & 67 & 84 & $15.4 \pm 3$ & $21.0 \pm 3$ & $25.7 \pm 3$ & 33 & 33 & 75 \\
\hline Acer pseudoplatanus* & 33 & 37 & 32 & $11.2 \pm 3$ & $9.0 \pm 2$ & $8.9 \pm 2$ & 9 & 15 & 11 \\
\hline Betula spp. & 31 & 32 & 22 & $3.6 \pm 1$ & $4.9 \pm 1$ & $4.8 \pm 1$ & 12 & 5 & 1 \\
\hline Quercus robur & 25 & 13 & 12 & $2.8 \pm 1$ & $2.2 \pm 1$ & $2.7 \pm 1$ & 3 & 2 & 0 \\
\hline Acer campestre & 38 & 35 & 42 & $0.2 \pm 0.1$ & $1.4 \pm 0.5$ & $3.0 \pm 0.1$ & 9 & 10 & 10 \\
\hline Quercus cerris* & 22 & 13 & 1 & $0.1 \pm 0.1$ & 0 & 0 & 0 & 0 & 0 \\
\hline $\begin{array}{l}\text { Other broadleaves/yew (10 } \\
\text { spp. })^{1}\end{array}$ & 54 & 43 & 29 & $4.5 \pm 2$ & $4.6 \pm 1$ & $3.6 \pm 1$ & 5 & 3 & 9 \\
\hline Introduced conifers (5 spp.) $)^{2}$ & 26 & 16 & 8 & $9.6 \pm 2$ & $3.8 \pm 1$ & $3.2 \pm 1$ & 6 & 0 & 0 \\
\hline \multicolumn{10}{|l|}{ Shrubs } \\
\hline Crataegus spp. & 61 & 66 & 55 & $0.9 \pm 0.4$ & $3.8 \pm 1$ & $3.6 \pm 1$ & 26 & 18 & 20 \\
\hline Corylus avellana & 48 & 53 & 54 & $10.7 \pm 2$ & $8.5 \pm 2$ & $14.1 \pm 2$ & 12 & 9 & 1 \\
\hline Cornus sanguinea & 67 & 49 & 25 & $2.8 \pm 1$ & $0.4 \pm 0.1$ & $0.2 \pm 0.1$ & 45 & 23 & 14 \\
\hline Ligustrum vulgare & 21 & 20 & 14 & $0.1 \pm 0.1$ & 0.0 & 0.0 & 12 & 12 & 5 \\
\hline Other shrubs (6 spp.) $)^{3}$ & 44 & 40 & 19 & $0.9 \pm 0.4$ & $0.5 \pm 0.3$ & $0.1 \pm 0.1$ & 19 & 4 & 9 \\
\hline
\end{tabular}

Other species were: ${ }^{1}$ Alnus glutinosa, Castanea sativa, Carpinus betulus, Ilex aquifolium, Populus spp., Prunus avium, Salix spp., Sorbus aucuparia, Taxus baccata, Ulmus spp.; ${ }^{2}$ Larix spp., Picea abies, Pinus nigra, P. sylvestris, Pseudotsuga menzesii ; ${ }^{3}$ Clematis vitalba, Euonymus europaeus, Prunus spinosa, Rhamnus catharticus, Sambucus nigra, Viburnum opulus . Non-native broadleaves are indicated by *

Table 3. Mean basal area of trees estimated through relascope scores at the plot locations.

\begin{tabular}{|c|c|c|c|c|c|c|}
\hline & \multicolumn{3}{|c|}{ Basal area (m²/ha) } & \multicolumn{3}{|c|}{ As \% of total } \\
\hline & 1973 & 1992 & 2009 & 1973 & 1992 & 2009 \\
\hline All species & $12.9 \pm 0.9$ & $18.1 \pm 0.9$ & $32.8 \pm 1.1$ & 100 & 100 & 100 \\
\hline \multicolumn{7}{|l|}{ Species contributions } \\
\hline Fagus sylvatica & $3.5 \pm 0.6$ & $4.7 \pm 0.8$ & $7.8 \pm 1.2$ & 27 & 26 & 24 \\
\hline Fraxinus excelsior & $2.5 \pm 0.5$ & $4.4 \pm 0.6$ & $11.8 \pm 1.4$ & 19 & 24 & 36 \\
\hline Acer pseudoplatanus & $1.4 \pm 0.4$ & $1.8 \pm 0.4$ & $2.9 \pm 0.6$ & 11 & 10 & 9 \\
\hline Betula spp. & $0.9 \pm 0.1$ & $1.6 \pm 0.3$ & $2.3 \pm 0.5$ & 7 & 9 & 7 \\
\hline Quercus robur & $0.7 \pm 0.1$ & $1.1 \pm 0.2$ & $2.2 \pm 0.5$ & 5 & 6 & 7 \\
\hline Acer campestre & $0.1 \pm 0.1$ & $0.4 \pm 0.1$ & $0.7 \pm 0.1$ & 1 & 2 & 2 \\
\hline Quercus cerris & $<0.1$ & $<0.1$ & 0 & $<1$ & $<1$ & 0 \\
\hline Other broadleaves/yew (12 spp.) ${ }^{1}$ & $0.8 \pm 0.2$ & $1.3 \pm 0.3$ & $1.9 \pm 0.3$ & 6 & 7 & 6 \\
\hline Introduced conifers (5 spp.) ${ }^{2}$ & $3.0 \pm 0.3$ & $2.7 \pm 0.5$ & $3.2 \pm 0.6$ & 23 & 15 & 10 \\
\hline
\end{tabular}


The increase in basal area between 1973 and 2009 reflects the fact that most stands were relatively young in 1973 (as judged by tree size) and hence likely to be growing rapidly (Figure 4). In 1973, the mean diameter for the largest tree present of any species was $22 \pm 2 \mathrm{~cm}$, whereas by 2009 this had gone up to $31 \pm 2 \mathrm{~cm}$, with a shift to the right in the distribution of the modal tree size class.

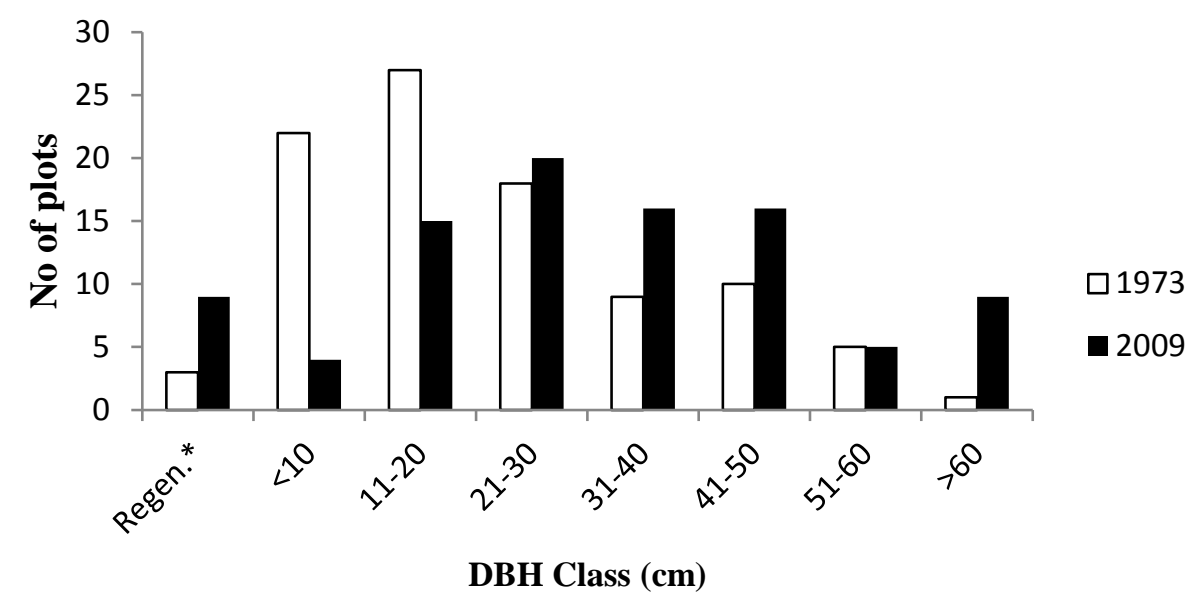

Figure 4. Diameter distribution for the single largest tree in each plot (all species) in 1973 and 2009. * Only seedlings, saplings or vegetative regrowth less than $1 \mathrm{~m}$ tall present in plot.

Using the data from the four largest trees in the plots to give a larger sample the commoner tree species showed distinct size distribution patterns (Figure 5). Beech was the species most likely to occur as large trees overall, but showed a bimodal distribution - in some plots the largest beech stems were only $20-30 \mathrm{~cm}$, whereas in a second set they were more than $40 \mathrm{~cm}$ (Figure $5 \mathrm{a}$ ). The smaller stems were often regrowth from old coppice stools, while the larger stems included some from areas that had a wood-pasture history.

Ash and birch (Figure 5b, 5c) have a typical young/invasive growth pattern with the peak cohort in the smallest DBH category in 1973 then moving through into larger size classes, but with little new recruitment. Sycamore showed a peak in 1973 at a larger size than for ash or birch suggesting an earlier primary regeneration event (Figure 5d). There were also a few larger (older) trees. By 2009 the main cohort had moved up a size class, but unlike ash there had also been some more recruitment into the smaller size classes- probably stump regrowth as few saplings were seen. The introduced conifers showed a similar main peak to sycamore in the 11-20 cm class, with few larger or smaller individuals (Figure 5e). However while the number of large trees was maintained the smaller size classes had largely disappeared by 2009.

\section{Variation across the reserve in relation to woodland origin}

Several of the major tree species showed distinct spatial patterns across the reserve in terms of their presence in the overstorey (Figure 6) which reflected differences in woodland origin (Figure 1). Beech was strongly associated with the ancient (pre-1800) woodland areas (Figure 6a). Ash was most common in early $19^{\text {th }}$ century plantation areas in the west of the site due to regrowth/invasion after the felling of the first plantation crop during the Second World War (Figure 6b). Sycamore and conifers were more in the late $19^{\text {th }}$ century plantation areas (Figure 6d, 6e). Birch was most common in the most recent stands and where subsequent clearance has occurred, in the centre of the valley (Figure $6 \mathrm{c})$. Oak and field maple showed no clear pattern over time or across the woodland origin types.

This variation was also seen in the contribution of the different species to mean basal area for the various woodland origin types (Table 4). The low value for total basal area in 2009 in the early 
$20^{\text {th }}$ century stands is because these had been opened up as part of the grassland restoration programme.

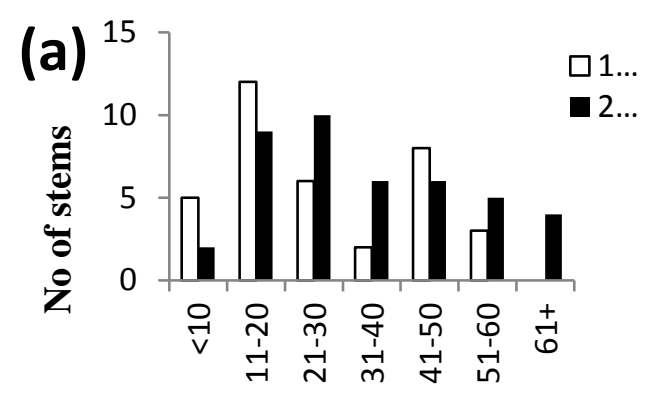

DBH Class (cm) Fagus sylvatica

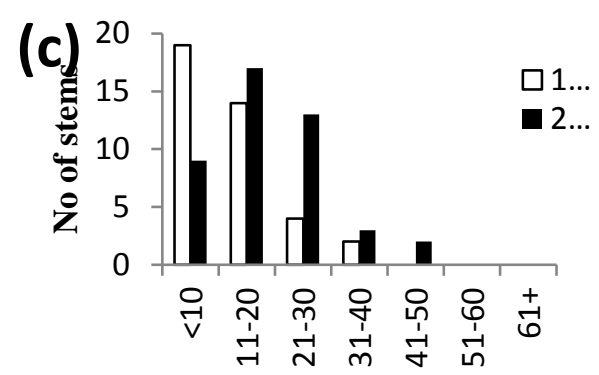

DBH Class (cm) Betula spp.

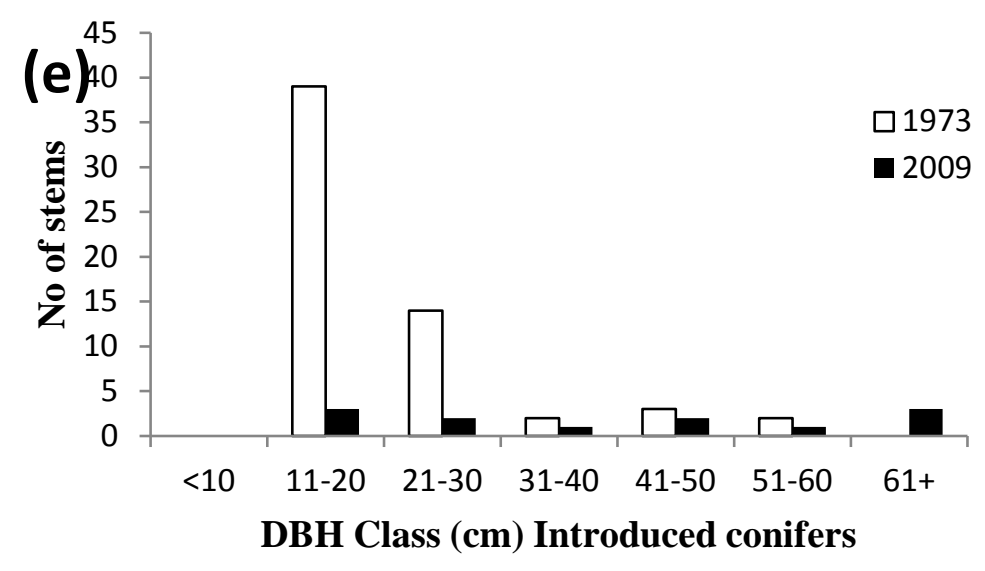

[Figure 5. Size distributions (diameter breast height DBH) for different species taken from records for the four largest trees (all species) in each plot: a. Fagus sylvatica, b. Fraxinus excelsior, c.Betula spp., d. Acer pseudoplatanus, e. introduced conifers.] 
(a) Fagus syivatica
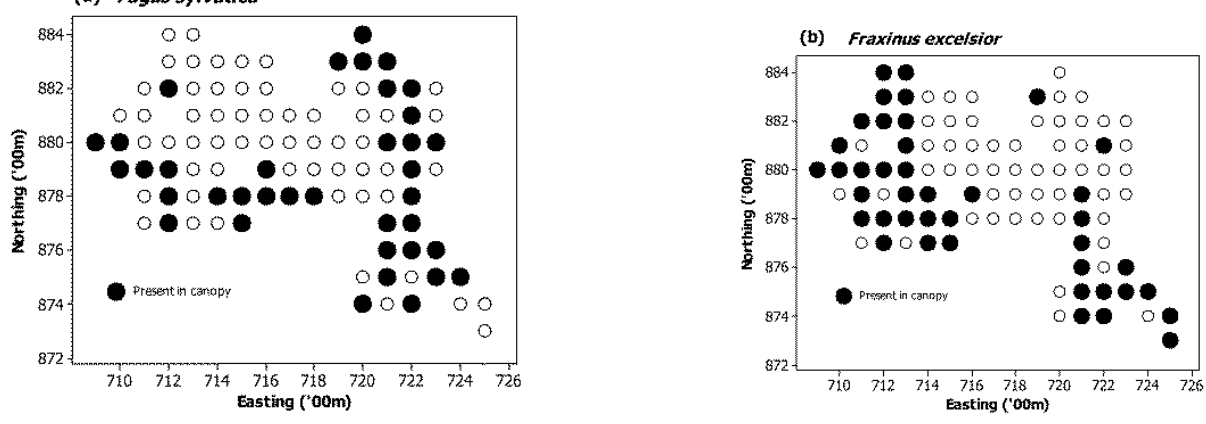

(c) Betula spp.
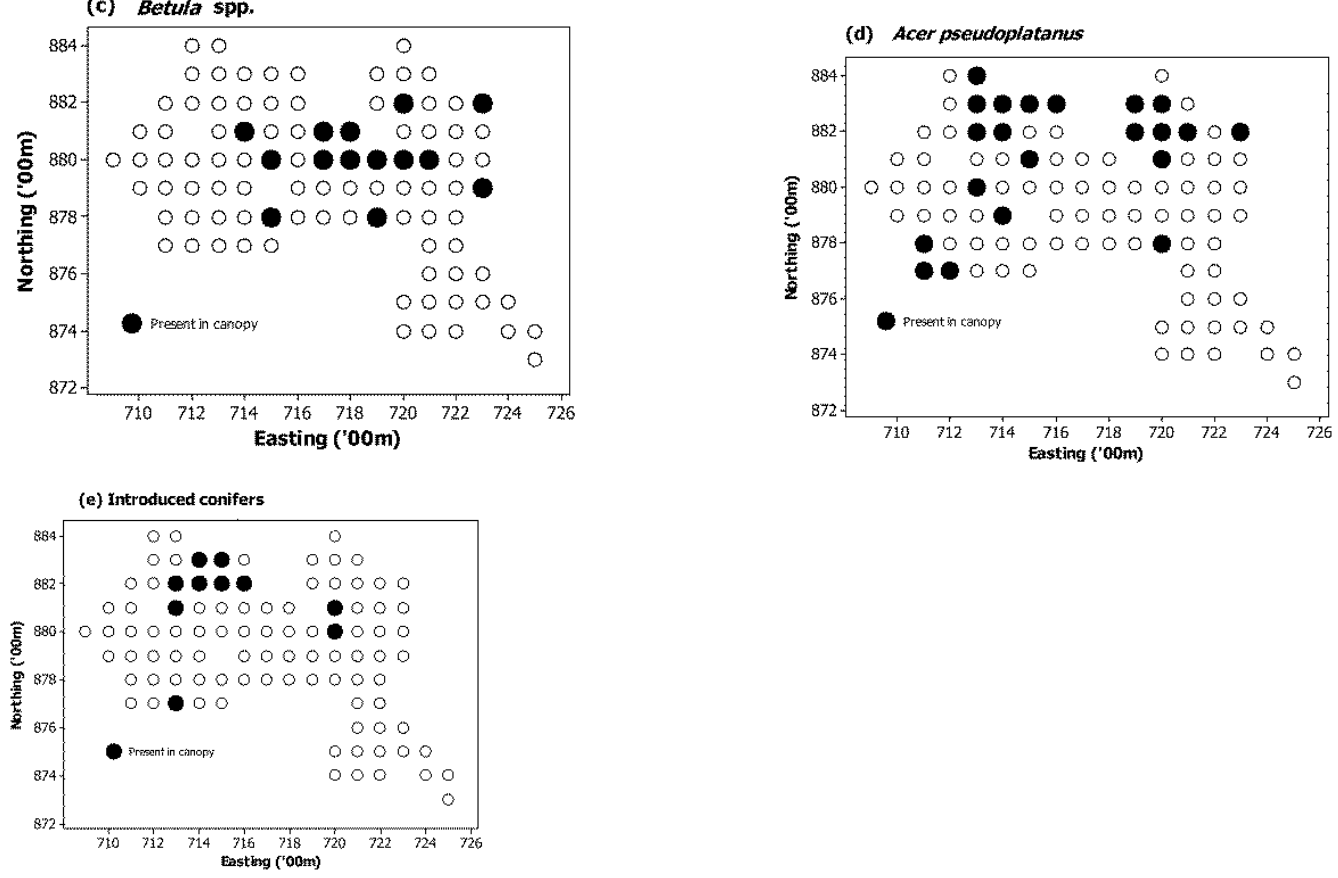

Figure 6. Species present (solid circles) in the overstorey in 2009: (a) Fagus sylvatica; (b) Fraxinus excelsior; (c) Betula spp. (d) Acer pseudoplatanus; (e) introduced conifers. 
Table 4. Mean basal area $\left(\mathrm{m}^{2} / \mathrm{ha}\right)$ for plots of different origins and the contribution of different tree species at the Warburg Reserve in 1973 and 2009 (excluding the one plot never wooded).

\begin{tabular}{|c|c|c|c|c|c|}
\hline & Origin & $\begin{array}{l}\text { Ancient } \\
\text { (pre- } \\
1800 \text { ) }\end{array}$ & $\begin{array}{l}\text { Early } \\
19^{\text {th }} \mathrm{C} .\end{array}$ & $\begin{array}{l}\text { Late } \\
19^{\text {th }} \text { C. }\end{array}$ & $\begin{array}{l}\text { Early } \\
20^{\text {th }} \mathrm{C} \text {. }\end{array}$ \\
\hline & No of plots & 36 & 14 & 33 & 11 \\
\hline All species (m²/ha) & 1973 & $13.5 \pm 1$ & $8.9 \pm 3$ & $15.1 \pm 1$ & $10.5 \pm 2$ \\
\hline \multicolumn{6}{|l|}{$\begin{array}{l}\text { Percentage } \\
\text { contributed by: }\end{array}$} \\
\hline \multirow[t]{2}{*}{ Fagus sylvatica } & 1973 & 53 & 44 & 2 & 0 \\
\hline & 2009 & 45 & 21 & 4 & 0 \\
\hline \multirow[t]{2}{*}{ Fraxinus excelsior } & 1973 & 26 & 33 & 15 & 0 \\
\hline & 2009 & 36 & 60 & 31 & 5 \\
\hline \multirow[t]{2}{*}{ Betula spp. } & 1973 & 1 & 2 & 8 & 30 \\
\hline & 2009 & 2 & 5 & 7 & 46 \\
\hline \multirow[t]{2}{*}{ Acer pseudoplatanus } & 1973 & 1 & 0 & 24 & 8 \\
\hline & 2009 & 1 & 1 & 23 & 5 \\
\hline \multirow[t]{2}{*}{ Introduced conifers ${ }^{2}$} & 1973 & 4 & 1 & 39 & 59 \\
\hline & 2009 & 2 & 1 & 21 & 24 \\
\hline \multirow[t]{2}{*}{ Quercus robur } & 1973 & 1 & 0 & 3 & 0 \\
\hline & 2009 & 1 & 1 & 8 & 2 \\
\hline \multirow[t]{2}{*}{ Acer campestre } & 1973 & 7 & 0 & 1 & 0 \\
\hline & 2009 & 8 & 1 & 3 & 6 \\
\hline \multirow[t]{2}{*}{ Other species ${ }^{1}$} & 1973 & 7 & 20 & 8 & 3 \\
\hline & 2009 & 5 & 10 & 3 & 20 \\
\hline
\end{tabular}

${ }^{1}$ Alnus glutinosa, Castanea sativa, Carpinus betulus, Ilex aquifolium, Malus sylvestris, Populus spp., Prunus avium, Quercus cerris, Salix spp., Sorbus aucuparia, Taxus baccata, Tilia spp., Ulmus spp.; ${ }^{2}$ Larix spp., Picea abies, Pinus nigra, P. sylvestris, Pseudotsuga menzesii

Impact of past and future tree diseases on woodland structure

Across all three recording periods elm was found in only eleven plots and never contributed more than $10 \%$ overstorey cover in any of them. The impact of Dutch elm disease on the structure of the reserve during this period of the study was therefore minimal. 
Ash occurred in about $90 \%$ of the plots in 2009, but contributed to the canopy in only $43 \%$. Overall it made up about a quarter of the overstorey cover (Table 2). However its contribution to the overstorey is strongly clustered (Figure 6b) such that it would be in west and the south-east of the reserve that the impact of ash dieback might be most serious. Twenty-four (70\%) of the thirty-four plots that contained more than $20 \%$ ash also had more than $25 \%$ cover of another tree species (Table 5). These other species could reduce any immediate change to the woodland environment if they expanded branches laterally into the gaps by ash death. Therefore about $10 \%$ of the Reserve is in the highest immediate impact category (high ash cover and little alternative cover).There is, though, a longer-term potential impact in that ash was the most common species recorded among regeneration (Table 2) across the whole reserve.

Table 5. Percentage cover of ash and of the other tree species that might replace it in the overstorey, as an indication of potential vulnerability to change through ash dieback.

\begin{tabular}{rrrrr}
\hline \% cover of ash in canopy & Ash absent & $\begin{array}{r}\text { Ash present, } \\
<20 \%\end{array}$ & $\begin{array}{r}\text { Ash }>20 \% \text {, other } \\
\text { species }>25 \%\end{array}$ & $\begin{array}{r}\text { Ash }>20 \% \text { other } \\
\text { species }<25 \%\end{array}$ \\
No of plots (out of 95) & 54 & 7 & 24 & $78 \pm 4$ \\
Mean \% cover of: & & $13 \pm 3$ & $65 \pm 3$ & \\
\hline Fraxinus excelsior & 0 & & & $10 \pm 4$ \\
& & $39 \pm 16$ & $5 \pm 2$ & 0 \\
Fagus sylvatica & $25 \pm 5$ & $23 \pm 15$ & $1 \pm 1$ & 0 \\
Acer pseudoplatanus & $10 \pm 3$ & 0 & $1 \pm 1$ & $1 \pm 1$ \\
Betula spp. & $8 \pm 2$ & $1 \pm 1$ & $6 \pm 2$ & 0 \\
Quercus robur & $4 \pm 2$ & $1 \pm 1$ & $3 \pm 2$ & 0 \\
Acer campestre & $3 \pm 1$ & 0 & $1 \pm 1$ & $1 \pm 1$ \\
Introduced conifers & $4 \pm 2$ & 0 & $12 \pm 4$ & $4 \pm 2$ \\
Crataegus spp. & $5 \pm 2$ & $17 \pm 11$ & $2 \pm 1$ & 0 \\
Corylus avellana & $16 \pm 3$ & 0 & & \\
Other trees & $1 \pm 1$ & & &
\end{tabular}

\section{Discussion}

\section{Comparison with other sites in Britain}

Much broadleaved woodland in Britain has grown up on open ground in the last 200yrs, and/or is composed of young growth following major fellings across the country during the Second World War (Foot 2010; Leslie 2014). On most sites there will have been at least one change of ownership during the course of broadleaved tree crop rotation, or, if not, the management objectives will have changed because of shifts in markets and government policies for forestry (Mason 2007). For example the emphasis on creating a strategic timber reserve in the early $20^{\text {th }}$ century, evolved into the promotion of economic timber production in the middle of the century, and then into the delivery of ecosystem services in the $21^{\text {st }}$ century.

Many woods are likely therefore to show the sorts of legacies of management shifts in the composition and structure that we found at the Warburg Reserve. For example Dawkins and Field (1978), who established the Warburg plots in 1973, set up a similar system at Wytham Woods about thirty kilometres to the north-west (Kirby et al. 2014). At Wytham there has also been an increase in ash, stability of the sycamore population and a decline in shrubs and planted conifers. Birch shows a more marked decline at Wytham, possibly because the population is somewhat older, having 
established during the Second World War, although the state forest service's (the Forestry Commission) census field sheet for the Warburg Reserve in 1947 also shows birch as abundant then. Old (large) trees at Wytham are more widespread and mainly oak; beech at Wytham is largely in $19^{\text {th }}$ century plantations, not in the ancient woodland as on the Warburg Reserve.

Reduction in the abundance of shrubs and other short-lived trees (Betula spp., Salix spp.) is reported from other sites with either increased shading or deer pressure (or both) seen as the main contributory factors (Peterken \& Jones 1989; Mountford \& Peterken 1998). Ash was noted as a species growing fast, filling gaps or showing the best regeneration in response to disturbances (Peterken \& Jones 1987; Mountford et al. 1998; Mountford \& Peterken 1998). Results from a resurvey of 103 broadleaved woods across Britain (Kirby et al. 2005) and from the National Forest Inventory (Forestry Commission 2012) confirm that across broadleaved woodland more generally in Britain, there is a preponderance of relatively young (small) stems; that basal area has been increasing in recent decades; and that there has often been a loss of shrubs and understorey species.

On the other hand, drought and storms appear to have had less impact at the Warburg Reserve on beech than at other sites where long terms studies have been made (Peterken \& Mountford 1996; Mountford \& Peterken 2003). Much of the beech on the reserve is on north-facing slopes or in narrow valleys which may be why they have been less affected by these events.

\section{Comparisons with studies elsewhere in Europe}

The particular results at the Warburg Reserve reflect that site's history, but some of the pressures and trends illustrated are common across Europe, for example an increase in woodland extent and in the overall standing volume of timber (Forest Europe 2015). Increases in ash (prior to the ash dieback outbreaks) have been reported (Hofmeister et al. 2004); at Suserup Forest in Denmark it has expanded into gaps created by windblow of beech and death of elm from disease (Emborg \& Heilmann-Clausen 2007).

There has been a decline in open woodland at many sites following the cessation of historic management practices such as coppicing or wood-pasture (e.g. Miklín \& Č́žek 2014). Brunet et al. (2014) suggest that the open spaces that might emerge from loss of ash through dieback, as is expected to occur at the Warburg Reserve, might provide opportunities to favour restoration of such important semi-open habitats.

Reaction against afforestation with conifers outside their native range has led to promotion of 'close to nature' type forestry systems (Bürgi 2015) and conversion of coniferous plantations to broadleaves, e.g. Zerbe (2002), mimicing the shift in the plantations at the Warburg reserve from even-aged, single species stands to more mixed and varied structures (albeit this change happened at the Warburg Reserve for a different reason).

\section{Relevance to the management of the Warburg Reserve}

Monitoring studies, as well as helping us understand long-term processes, should also provide a check on whether sites are developing in line with management objectives. The Warburg Reserve is designated for the conservation of its mosaic of native woodland, scrub and grassland habitats. The results reflect the success of removal of the remaining introduced conifers under recent conservation management. 
Restoration of open habitats, such as species-rich grassland, from plantations is also now encouraged under government policy (Forestry Commission 2010) - partially reversing the practice through much of the late $19^{\text {th }}$ /early $20^{\text {th }}$ century. The grassland areas at the Warburg Reserve have expanded, including in an area that was clear-felled by the previous owners in 1963 and initially planted up in the early years of the Wildlife Trust's tenure (Paul 1985)!

Non-native broadleaves (particularly Quercus cerris and Acer pseudoplatanus) were also targeted for felling and ring-barking. Quercus cerris is much reduced (Table 2) but the abundance of sycamore has changed little. Furthermore, possible future reductions in the cover of ash (from disease) and any disturbance associated with felling of diseased trees, for example, because they are dangerous and close to paths, are likely to favour regeneration of sycamore (Waters \& Savill 1992).

The potential future impact of ash dieback may require a review of management practice and advice is being developed as to how affected areas might be treated on protected sites (Natural England/Forestry Commission 2015; Reid et al. 2016). Our results suggest a number of possible options. The most important woodland areas are the ancient beech stands in which ash is not very abundant (Natural England undated; Figure 6a, b). Ash death elsewhere on the reserve, particularly in the former plantation areas is likely to create more heterogeneity in the stand structure, and more dead wood. This may reduce the need for more active interventions, such as coppicing, to counteract the general tendency for woods to have become more shaded in recent decades (Kirby et al. 2005; Hopkins \& Kirby 2007) with accompanying losses of species of glades and temporary clearings. Gaps from ash death could also be used to encourage beech into the more recent woodland where it is not currently that abundant, thus contributing to the expansion of a priority woodland type under the UK Biodiversity Action Plan. Other gaps might be used as the focus for further opening up of the overstorey to restore chalk grassland.

Other future pressures include climate change and the impacts of deer. Both beech and sycamore may be susceptible to increases in extreme summer droughts under the most likely climate change projections (Morecroft \& Speakman 2015). Deer numbers in southern Britain have increased compared to earlier decades (Ward 2005). At present both natural regeneration and coppice regrowth have to be protected by fencing and there is limited regeneration other than of ash. Deer culling may therefore need to be increased on the reserve.

\section{Conclusion}

As in many other woods, the status quo at the Warburg Reserve may not be sustainable in future. The main native tree species ash and beech, although they have been growing well in recent decades, are both potentially vulnerable to disease and climate change effects respectively. The third species which would appear to have the potential to spread and so help maintain a broadleaved woodland environment is sycamore, a non-native species that was previously controlled. There may need to be a new conservation management ethos to cope with the acceptance of such future-native species on some sites (Peterken 2001; Kirby 2013).

The tree and shrub layer in a wood is part of its biodiversity in its own right, but its species composition, age structure and spatial pattern have strong effects on other groups of organisms (for example Mitchell \& Kirby 1989; Mitchell et al. 2014). As illustrated in the Warburg results the tree and shrub changes are partly gradual and to a degree predictable - for example the development of the cohort of young ash - partly sudden and unpredicable such as the 1990 storm or the Dutch elm disease outbreak. 
Understanding these past changes in tree species, age and distribution through map and fieldbased studies should inform considerations of future woodland resilience (Forestry Commission 2015). However this may depend on what is the baseline variation in our woodland composition and structure against which future resilience is judged (Wiens et al. 2012). The Warburg Reserve might be regarded as potentially quite resilient - in the sense of having a wide range of tree and shrub species present with little variability in woodland extent, structure, or composition - judged just over recent decades and at the scale of the whole reserve. However if resilience is assessed at smaller spatial scales - the stand level - or longer temporal ones - a couple of centuries - then the level of variation in woodland extent, composition and structure is very much greater.

\section{Acknowledgements}

We are grateful to BBOWT for permission to work on the site and to Giles Alder, Nigel Phillips and Rod D'Ayala in particular for help in the field work. The Nature Conservancy Council and its successors allowed us the time to carry out the studies. Colyear Dawkins and David Field were responsible for devising and setting up the plot system, as well as for the 1973 recording, on which all subsequent work has been based. Two reviewers provided valuable comments that helped us to improve the paper.

\section{References}

Aldhous, J.R. (1997). British forestry: 70 years of achievement. Forestry, 70, 283-291.

Anon. (1994). Biodiversity: the UK action plan. London: HMSO.

Bakker, J. P., Olff, H., Willems, J. H. \& Zobel, M. (1996). Why do we need permanent plots in the study of long-term vegetation dynamics? Journal of Vegetation Science, 7, 147-156.

Barker-Plotkin, A. \& Foster, D. (2006). Sustaining long-term research through changing times at the Harvard Forest. Long-term silvicultural and ecological studies: Results for science and management. The Global Institute of Sustainable Forestry, 41-52.

BBOWT (2016). Warburg Nature Reserve. Available at http://www.bbowt.org.uk/reserves/warburgnature-reserve. Accessed 8/1/2016.

Bitterlich, W. (1984). The relascope idea. Relative measurements in forestry. Wallingford, UK: CABI

Brunet, J., Bukina, Y., Hedwall, P.-O., Holmström, E. \& Von Oheimb, G. (2014). Pathogen induced disturbance and succession in temperate forests: Evidence from a 100-year data set in southern Sweden. Basic and Applied Ecology, 15, 114-121.

Bürgi, M. (2015). Close to nature forestry. In: K.J. Kirby \& C.Watkins, C. (eds.) Europe's changing woods and forests: from wildwood to managed landscapes. (pp.107-115). Wallingford, UK: CABI.

Dawkins, H.C.D. \& Field, D.R.B. (1978). A long-term surveillance system for British woodland vegetation. Commonwealth Forestry Institute Occasional Paper 1. Oxford: Commonwealth Forestry Institute.

Edlin, H.L. (1949). Woodland crafts in Britain. London: Batsford. 
Emborg, J. \& Heilmann-Clausen, J. (2007). The structure of Suserup Skov, 2002. The first remeasurement of a long-term permanent plot study of forest dynamics started in 1992. Ecological Bulletins, 52, 19-32.

European Commission (1992). Directive on the conservation of natural habitats and wild fauna and flora: the habitats directive, 92/43/EEC, Brussels: European Commission.

Foot, D. (2010). Woods and people: putting forestry on the map. Stroud, UK, The History Press.

Forest Europe (2015). State of Europe's Forests. Madrid: Ministerial Conference on the Protection of Forests in Europe Liaison Unit.

Forestry Commission (2010). When to convert woods and forests to open habitat in England: government policy. Bristol: Forestry Commission.

Forestry Commission (2012). NFI preliminary estimates of quantities of broadleaved species in British woodlands, with special focus on ash. Edinburgh: Forestry Commission..

Forestry Commission (2015). Adapting England's woodland to be more resilient. Available at: http://www.forestry.gov.uk/england-resilience.Accessed 8/1/2016.

Foster, D. R., Motzkin, G. \& Slater, B. (1998). Land-use history as long-term broad-scale disturbance: regional forest dynamics in central New England. Ecosystems, 1, 96-119.

Gibbs, J.N. (1978). Development of the Dutch elm disease epidemic in southern England, 1971-6. Annals of Applied Biology, 88, 219-228.

Goldberg, E.A., Kirby, K.J., Hall, J.E. \& Latham, J. (2007). The ancient woodland concept as a practical conservation tool in Great Britain. Journal of Nature Conservation, 15, 109-119.

Hofmeister, J., Mihaljevič, M. \& Hošek, J. (2004). The spread of ash (Fraxinus excelsior) in some European oak forests: an effect of nitrogen deposition or successional change? Forest Ecology and Management, 203, 35-47.

Hopkins, J.J. \& Kirby, K.J. (2007). Ecological change in British broadleaved woodland since 1947. Ibis, 149, 29-40.

Kirby, K. J. 2013. Tree species and provenance choice in high value conservation sites. Quarterly Journal of Forestry, 107, 223-227.

Kirby, K. J. \& Buckley, G. P. (1994). Ecological responses to the 1987 Great Storm in the woods of south-east England. English Nature Science 23. Peterborough: English Nature.

Kirby, K. \& Thomas, R. (2000). A comparison of the structure and composition of the Warburg Reserve between 1973 and 1992. English Nature Research Report 445. Peterborough: English Nature.

Kirby, K.J. \& Watkins, C. (2015). Europe's changing woods and forests: from wildwood to managed landscapes. Wallingford, UK, CABI.

Kirby, K.J., Bazely, D.R., Goldberg, E.A., Hall, J.E., Isted, R., Perry, S.C. \& Thomas, R.C. (2014). Changes in the tree and shrub layer of Wytham Woods (southern England) 1974-2012: local and national trends compared. Forestry, 87, 663-673. 
Kirby, K. J., Smart, S. M., Black, H. J., Bunce, R. G. H., Corney, P. M. \& Smithers, R. J. (2005). Long-term ecological changes in British woodland (1971-2001). English Nature Research Report 653. Sheffield: English Nature.

Koop, H. \& Hilgen, P. (1987). Forest dynamics and regeneration mosaic shifts in unexploited beech (Fagus sylvatica) stands at Fontainebleau (France). Forest Ecology and Management, 20, 135-150.

Latałowa, M., Zimmy, M., Jedrejewska, B. \& Samojlik, T. 2015. Białowieża Primeval Forest - 2000year interplay of environmental and cultural forces in Europe's best preserved temperate woodland. In: K.J. Kirby \& C.Watkins, C. (eds.) Europe's changing woods and forests: from wildwood to managed landscapes. (pp.243-264). Wallingford, UK: CABI.

Leslie, R. (2014). Forest Vision:transforming the Forestry Commission. Bristol: New Environment Books.

Lindbladh, M. \& Foster, D. R. (2010). Dynamics of long-lived foundation species: the history of Quercus in southern Scandinavia. Journal of Ecology, 98, 1330-1345.

Magnuson, J. J. (1990). Long-term ecological research and the invisible present. Bioscience, 40, 495501.

Mason, W. (2007). Changes in the management of British forests between 1945 and 2000 and possible future trends. Ibis, 149, 41-52.

Miklín, J. \& Čížek, L. (2014). Erasing a European biodiversity hot-spot: open woodlands, veteran trees and mature forests succumb to forestry intensification, succession, and logging in a UNESCO Biosphere Reserve. Journal for Nature Conservation, 22, 35-41.

Mitchell, P. L. \& Kirby, K. J. (1989). Ecological effects of forestry practices in long-established woodland and their implications for nature conservation. Occasional Paper 39. Oxford: Oxford Forestry Institute.

Mitchell, R.J., Beaton, J.K., Bellamy, P.E., Broome, A., Chetcuti, J., Eaton, S., Ellis, C J., Gimona, A., Harmer, R., Hester, A.J., Hewison, R.L., Hodgetts, N.G., Iason, G.R., Kerr, G., Littlewood, N.A., Newey, S., Potts, J.M., Pozsgai, G., Ray, D., Sim, D.A., Stockan, J.A., Taylor, A.F.S. \& Woodward, S. (2014). Ash dieback in the UK: A review of the ecological and conservation implications and potential management options. Biological Conservation, 175, 95-109.

Morecroft, M.D. \& Speakman, L. (2015) Biodiversity Climate Change Impacts Summary Report. Living With Environmental Change. Available at: http://www.nerc.ac.uk/research/partnerships/lwec/products/report-cards/biodiversity/reportcard/. Accessed 8/1/2016.

Mountford, E P. (1997). A decade of grey squirrel bark-stripping damage to beech in Lady Park Wood, UK. Forestry, 70, 17-29. 
Mountford, E.P. (2006). Long-term patterns and impacts of grey squirrel debarking in Lady Park Wood young-growth stands (UK). Forest Ecology and Management, 232, 100-113.

Mountford, E.P. \& Peterken, G.F. (1998). Monitoring natural change in Monks Wood National Nature Reserve. English Nature Research Report 270. Peterborough: English Nature.

Mountford, E. P. \& Peterken, G.F. (2003). Long-term change and implications for the management of wood-pastures: experience over 40 years from Denny Wood, New Forest. Forestry, 76, 1943.

Mountford, E.P., Peterken, G.F. \& Burton, D. (1998). Long-term monitoring and management of Langley Wood: a minimum intervention National Nature Reserve. English Nature Research Report 302. Peterborough: English Nature.

Müllerová, J., Hédl, R. \& Szabó, P. (2015). Coppice abandonment and its implications for species diversity in forest vegetation. Forest Ecology and Management, 343, 88-100.

Natural England (Undated). Bix Bottom SSSI citation. Available at: http://www.sssi.naturalengland.org.uk/citation/citation_photo/1001558.pdf. Accessed 8/1/2016.

Natural England (2013). NCA Profile:110 Chilterns (NE406). Available at: http://publications.naturalengland.org.uk/publication/4977697. Accessed 8/1/2016.

Natural England/Forestry Commission (2015). What can we do about "Chalara” ash dieback (Hymenoscyphus fraxineus) on woodland SSSIs? Available at: http://rfs.org.uk/media/160458/ash-dieback-sssi-management-advice-april-2015.pdf. Accessed 8/1/2016.

Old-maps.co.uk. Undated. Historic Ordnance Survey Maps. Available at: https://www.oldmaps.co.uk/index.html\#/Map/472500/185500/12/101270. Accessed 8/1/2016.

Paul, V.N. (1985). The Warburg Reserve: a case study. In: R. Fitter (ed.) Wildlife in the Thames counties: Berkshire, Buckinghamshire and Oxfordshire (pp.180-192). Oxford: Robert Dugdale.

Pautasso, M., Aas, G., Queloz, V. \& Holdenrieder, O. (2013). European ash (Fraxinus excelsior) dieback - A conservation biology challenge. Biological Conservation, 158, 37-49.

Perrin, P. M., Kelly, D. L. \& Mitchell, F. J. G. (2006). Long-term deer exclusion in yewwood and oakwood habitats in south-west Ireland: natural regeneration and stand dynamics. Forest Ecology and Management, 236, 356-367.

Peterken, G.F. (2001). Ecological effects of introduced tree species in Britain. Forest Ecology and Management, 141, 31-42.

Peterken, G.F. \& Backmeroff, C. (1988). Long-term monitoring in unmanaged nature reserves. Research and Survey in Nature Conservation 9. Peterborough: Nature Conservancy Council. Peterken, G.F. \& Jones, E.W. (1987). Forty Years of Change in Lady Park Wood: The Old-Growth Stands. Journal of Ecology, 75, 477-512. 
Peterken, G.F. \& Jones, E.W. (1989). Forty years of change in Lady Park Wood: the young growth stands. Journal of Ecology, 77, 401-429.

Peterken, G.F. \& Mountford, E P. (1996). Effects of drought on beech in Lady Park Wood, an unmanaged mixed decidous woodland. Forestry, 69, 125-136.

Peterken, G F. \& Mountford, E.P. (1998). Long-term change in an unmanaged population of wych elm subjected to Dutch elm disease. Journal of Ecology, 86, 205-218.

Phillips, N. (1991). The Warburg Reserve Management Plan 1992-1997. (Unpublished ms.) Oxford: BBOWT.

Pontailler, J.-Y., Faille, A. \& Lemée, G. (1997). Storms drive successional dynamics in natural forests: a case study in Fontainebleau forest (France). Forest Ecology and Management, 98, $1-15$.

Rackham, O. (1986). The history of the countryside. London: Dent.

Rackham, O. (2003). Ancient woodland: its history, vegetation and uses in England (revised edition), Dalbeattie: Castlepoint Press.

Reid, C.M., Goldberg, E.A. \& Alsop, J. (2016). Responses to ash dieback on woodland SSSIs. Quarterly Journal of Forestry, 110, 31-36.

Rochel, X. (2015). Forest management and species composition: a historical approach in Lorraine, France. In: K.J. Kirby \& C.Watkins, C. (eds.) Europe's changing woods and forests: from wildwood to managed landscapes. (pp.279-289). Wallingford, UK: CABI.

Rodwell, J.S. (1991). British plant communities: 1 woodlands and scrub, Cambridge: Cambridge University Press.

Rodwell, J.S. (1992). British plant communities: 3 grasslands and montane communities, Cambridge: Cambridge University Press.

Spencer, J.W. \& Kirby, K J. (1992). An inventory of ancient woodland for England and Wales. Biological Conservation, 62, 77-93.

Stace, C. (1991). New flora of the British Isles. Cambridge: Cambridge University Press.

Tilney-Bassett, H.A.E. (1988). Forestry in the Region of the Chilterns. Forestry, 61, 267-286.

Von Oheimb, G. \& Brunet, J. (2007). Dalby Söderskog revisited: long-term vegetation changes in a south Swedish deciduous forest. Acta Oecologica, 31, 229-242.

Ward, A.I. (2005). Expanding ranges of wild and feral deer in Great Britain. Mammal Review, 35, $165-173$

Waters, T.L. \& Savill, P.S. (1992). Ash and sycamore regeneration and the phenomenon of their alternation. Forestry, 65, 417-433.

Webb, M.F. (1987). The history of the Warburg Reserve and surrounding area. Oxford: Oxford Brookes University.

Wiens, J.A., Hayward, G.D., Safford, H.D. \& Giffen, C.M. (eds) (2012). Historical environmental variations in conservation and natural resource management, Chichester: Wiley-Blackwell. 
Wikepedia (2008) Relascope. Available at https://en.wikipedia.org/wiki/Relascope\#Point_sampling. Accessed 8/1/2016.

Zerbe, S. (2002). Restoration of natural broad-leaved woodland in Central Europe on sites with coniferous forest plantations. Forest Ecology and Management, 167, 27-42. 